\title{
The Location of Refugee Female Teachers in the Canadian Context: "Not Just a Refugee Woman!"
}

\author{
SNEŽAna RATKović
}

\begin{abstract}
This paper explores intersectionality of oppression and social agency in refugee narratives of four female teachers from Yugoslavia who immigrated to Ontario and Quebec between 1994 and 1998. These narratives reveal a number of systemic barriers participants encountered in their new country, such as lack of coordination between immigration and settlement services, lack of information about the teacher recertification process, systemic ignorance towards international teaching credentials and experiences, and a number of settlement practices that pushed the participating women teachers to the margins of the Canadian educational system. In addition to reporting a number of systemic barriers to teaching, these women also revealed self-imposed psychological and culturally constructed barriers to settlement such as personal perceptions of having limited language competencies, of being "too old" to continue education, and of remaining permanent outsiders to Canadian ways of being. Women also discussed their choices and priorities in terms of their personal and professional lives and the ways in which these preferences facilitated and/or hindered their integration in the Canadian education system and society. The paper challenges the master narrative of refugeehood in Canada by exposing the ways in which race, class, gender, age, ethnicity, and professional identity, in addition to refugeehood, shape the oppression and the privilege of refugee women in the Canadian context.
\end{abstract}

\begin{abstract}
Résumé
Cet article explore l'interaction entre les limitations et l'aptitude sociale au cour des récits de quatre enseignantes yougoslaves qui ont immigré en Ontario et au Québec entre 1994 et 1998. Leur récit révèle plusieurs barrières systémiques auxquelles ces femmes ont été confrontées dans leur nouveau pays, telles que le manque de coordination entre les services de l'immigration et les services à l'établissement, le manque d'information au sujet $d u$ processus de certification des enseignants, l'ignorance systémique des expériences et des reconnaissances internationales en enseignement et des pratiques de résolution, qui ont refoulé ces enseignantes vers les marges du système canadien d'éducation. En plus de signaler ces barrières à leur activité d'enseignante, ces femmes ont également dévoilé des limites psychologiques et culturelles qu'elles se sont imposées et qui ont nuit à leur établissement, telles que leur perception de leur compétences linguistiques réduites, d'être trop vieille pour poursuivre leur éducation, et de demeurer malgré tout étrangères au mode de vie canadien. Ces femmes ont également discuté de leurs choix et de leurs priorités dans le cadre de leur vie personnelle et professionnelle, et comment ces décisions ont facilité ou freiné leur intégration dans la société et le système d'éducation canadiens. Cet article conteste le discours courant sur les réfugiés au Canada en mettant en lumière comment la race, la classe, le sexe, l'âge, l'ethnicité, et l'identité professionnelle, en plus du statut de réfugié, contribuent aux limitations et privilèges des femmes réfugiées dans le contexte canadien.
\end{abstract}


I am a woman. I am a person with much potential, I wouldn't say quality, I don't know how somebody would judge that, quality or not quality but potential [sighs]. I like to challenge, expand, I am a person that could be very useful, and it's popular to say [I could be very useful] in making a difference [laughs].

-Zlata, Interview 1, May 2010

$\mathrm{C}$ anada has been recognized as a leading advocate of international refugee protection and the third largest settlement country, with eleven thousand new asylum claims received each year. In 2008, the Conference Board of Canada suggested increasing immigration levels and refugee intakes in the country to meet Canada's economic needs. ${ }^{1}$ The Board also stated that the Canadian immigration system must be transparent about the selection criteria, working conditions, and available supports for immigrants and refugees, as well as responsive to the immigrants' and refugees' needs and expectations. However, credentials and skills of highly educated immigrants and refugees are often ignored in the host country.

Refugees leave their countries under extreme conditions and come to Canada to re-establish their lives. The Office of the High Commissioner for Human Rights defines a refugee as:

A person who is outside his/her country of nationality or habitual residence; has a well-founded fear of persecution because of his/ her race, religion, nationality, membership in a particular social group or political opinion; and is unable or unwilling to avail himself/herself of the protection of that country, or to return there, for fear of persecution. ${ }^{2}$

Such a definition, while providing some useful criteria, hides the differences across individuals and groups assigned the refugee label and contributes to a portrait of refugees that is far too simplistic and therefore problematic. More specifically, this definition does not address the complexities of refugee experiences often negotiated through and shaped by the intersections of race, class, gender, age, ethnicity, and professional identity. Citizenship and Immigration Canada provides additional insights into refugee experiences by describing refugees as Government Assisted Refugees, Privately Sponsored Refugees, Refugee Dependants Abroad, or Asylum Refugees. Although helpful in terms of developing immigration and settlement policies and practices, these categories continue to ignore other differences among refugees, which are often based on refugees' social location such as race, gender, and class.
This paper is a part of a larger study interrogating transitions, experiences, and identities of ten refugee female teachers from Yugoslavia who immigrated to Ontario and Quebec between 1994 and 1998, during and after the civil war in the country (1991-1995). For the purposes of this paper, I document intersectionalities of oppression and social agency in refugee narratives of four female teachers from Yugoslavia. Firstly, I discuss the theoretical lens and refugee literature used to analyze participants' narratives. Secondly, I report systemic barriers to teaching encountered by these women in Ontario and Quebec, their self-imposed psychological and culturally constructed barriers, and their personal choices and priorities. Thirdly, I describe the ways in which these women encountered and discussed neoliberalism - a dominant discourse in Canada that emphasizes self-responsibility for one's place in the society. Fourthly, I challenge the master narrative of refugeehood in Canada by exploring the ways in which race, class, gender, age, ethnicity, and professional identity shaped the oppression and the privilege of the refugee women teachers participating in this study.

\section{Theoretical Framework: Post-colonial Feminism, Intersectionality, and Identity}

The refugee label is often perceived to be a symbol of disadvantage, as are other labels, such as immigrant, visible minority, and Third-World woman. ${ }^{3}$ According to Khayatt, the perception of refugees as disadvantaged people raises the issue of discrimination and reveals the danger of labelling and marginalizing groups and individuals. ${ }^{4}$ Uma Narayan challenges the process of sorting people into homogeneous and fixed categories by complicating the sense of what it means to "inhabit a culture," especially the culture of a Third-World woman and feminist. She explains:

\footnotetext{
Finally, though calling myself a Third-World feminist is subject to qualification and mediation, it is no more so than many labels one might attach to oneself-no more so than calling myself an Indian, a feminist, or a woman, for that matter, since all these identities are not simple givens but open to complex ways of being inhabited, and do not guarantee $m$ a $n$ specific experiences or concerns, even as they shape one's life in powerful ways. ${ }^{5}$
}

In the excerpt above, Narayan points out the danger of labelling individuals and groups and highlights the intersectionality of ethnicity, gender, and epistemology in one's life. She argues that human experiences are diverse, unpredictable, and negotiated.

Chandra Talpade Mohanty also draws attention to intersectionality in people's lives: "It is the current intersection 
of anti-racist, anti-imperialist and gay and lesbian struggles which we need to understand to map the ground for feminist political strategy and critical analysis." 6 She examines race, empire, and citizenship in US feminist projects and observes that corporate cultures of power, domination, and surveillance overlap with a politics of complicity in the US academy. ${ }^{7}$ Mohanty urges progressive scholars to analyze the language of imperialism and empire: "Theorizing the place of immigrant, poor women of color in the citizenship narrative of Women's Studies, and challenging the rescue narrative of privileged US feminists wherever it appears is a crucial aspect of feminist solidarity praxis at this time." 8

In order to theorize the place of refugee women in the Canadian citizenship narrative, I explore how intersections of race, class, gender, age, ethnicity, professional status, and refugeehood condition and complicate refugee women's lives in the Canadian context.

\section{Literature Review: Women, Refugeehood, and (Professional) Identity}

Refugee women in particular are a highly vulnerable segment of the population because of both physical realities and traditional cultural roles. The gap between refugee women's pre-exile and exile professional and socio-economic status is often so wide that it becomes hard to overcome, regardless of the fact that women are already used to balancing multiple roles and responsibilities (e.g. working and caring for the family at the same time). Nikolić-Ristanović states:

In refuge, they [refugee women] often bear a heavier burden of physical work, to which they are not accustomed. In addition, their education and previous experience turn out to be insufficient for finding a suitable job in their field in the country of asylum. ${ }^{9}$

Refugee women teachers, in general, encounter multiple challenges in re-establishing their teaching careers in a new country. Some of the key challenges reported in the literature include: non-recognition of teaching credentials and work experience, ${ }^{10}$ lack of proficiency in the official language, ${ }^{11}$ lack of cross-cultural knowledge and a lack of familiarity with the multicultural student population, ${ }^{12}$ and negative stereotyping and discrimination by potential employers and government services, as well as domestic responsibilities and financial difficulties. ${ }^{13}$

\section{Unsettled in Canada}

In Canada, refugee women teachers are oppressed not only by their refugee status and gender, but also by the workings of competition, "a salient feature of neoliberalism."14 The free market in the neoliberal context sees its citizens as solely responsible for their success in the society. Social responsibility for systemic inequities vanishes in the light of the individual's responsibility for his/her place in the social and economic order. This view perpetuates the production of a "permanent underclass, and even a permanent criminal class, along with a class of aliens, or noncitizens." ${ }^{15}$ In such a context, even university-educated refugee women teachers are unable to find jobs and often suffer high levels of poverty. ${ }^{16}$ Even when refugee women teachers succeed in finding employment, they usually obtain short-term, low-wage, non-teaching jobs. ${ }^{17}$ These women find themselves first and foremost constructed as refugee women and continue to be re-presented as an economically, socially, and politically marginalized group.

The location of the refugee female teacher within the Canadian neoliberal context is further troubled by myths and stereotypes which are deeply embedded in the master narrative of forced migration. This master narrative warns us that refugee women come to Canada to do the "dirty work"18 and "steal jobs from Canadian-born women."19 They "get into Canada by manipulating the system and bring with them their problems and conflicts" 20 to this refugee-welcoming country. Refugee women are often portrayed as uneducated women of colour who do not speak English or French ${ }^{21}$ and as women who are "more feminine, docile, sexually available, obedient." 22

According to Morris and Sinnott, refugee women in general, and refugee female teachers in particular, are often perceived as being different from the mainstream groups in Canada (i.e., different from those who are white, Canadianborn, and English-speaking). ${ }^{23}$ In the same vein, $\mathrm{Ng}$ and Shan argue that a lack of recognition of international teaching credentials is a form of othering that underlines " $\mathrm{a}$ colonial legacy that downgrades education, training and credentials from non-Western societies, thereby re-inscribing and exacerbating existing inequalities based on age, gender, and race." 24

\section{Border Pedagogies and Borderless Possibilities}

Over the past decade, the Canadian classroom has become more culturally and linguistically diversified. The teacher population, however, does not mirror such classroom diversity. ${ }^{25}$ Furthermore, the research indicates that Canadian teachers - who are mostly white, middle class and femaleare often poorly prepared for teaching students of diverse cultural and linguistic backgrounds. ${ }^{26}$ Armstrong and McMahon warn: "The reforms have failed to deliver their espoused targets of excellence, equality, and high achievement for urban students, particularly as they relate to social class, race, ethnicity, language, and gender."27 
Dlamini and Martinovic urge educators to recognize the value and the potential of a diverse student/teacher population in Canada:

...diverse classes-classes that work in and in between two or more languages and cultures to create students and teachers as engaged brokers, investigators, participants and producers of culture, language and identity-would provide a more complex, rich and politically sensitive learning experience. ${ }^{28}$

Dlamini invites schools and faculties of education to embrace border pedagogy and "re-imagine the mainstream as intercultural and multilingual in make-up." 29 She references Giroux and argues for the implementation of border pedagogy as a tool for progressive classroom teaching, a pedagogy that employs difference as an analytical tool and encourages students to cross over "into cultural borders that offer narratives, languages and experiences that provide a resource for rethinking the relationship between the centre and the margins of power as well as between themselves and others." 30 According to Giroux, border pedagogy is linked to critical democracy. ${ }^{31}$ Educators must understand the frameworks in which "difference is constructed through various representations and practices that name, legitimate, marginalize, and exclude the voices of subordinate groups." 32 Border pedagogy does not simply recognize difference as a social and historical construct, but makes the axes of power visible within and across educational settings. Such a pedagogy should be seen as a site for critical analysis, creativity, and possibility:

\footnotetext{
...these pedagogical borderlands where blacks, whites, latinos [sic] and others meet demonstrate the importance of a multicentric perspective that allows students to recognise and analyse how the differences within and between various groups can expand the potential of human life and democratic possibilities. ${ }^{33}$
}

Dlamini warns, however, that border pedagogy fails to ask the fundamental questions about power in the classroom and can produce "a further marginalization of the very discourses it aims to elevate." 34 Therefore, teachers must understand that border pedagogy is not only about teaching new skills and knowledges but also about challenging belief systems, ways of living, and social privileges "that others would kill to safeguard." 35

Issues of representation remain crucial in educating a socially and culturally diverse student population. Teachers from a variety of racial and ethnic backgrounds

not only provide role models for minority youth, but bring diverse teaching styles, modes of communication and knowledge into schools for the benefits of all students...and enhance learning opportunities for all students who must learn to exist within an increasingly globalized local context. ${ }^{36}$

Therefore, constructing and sustaining diverse classrooms in Canada requires modelling acceptance, appreciating difference, and fostering equity and social justice. In this context, refugee female teachers can be perceived as key players in the implementation of border pedagogy and development of social justice education. According to Carr and Klassen, teachers of diverse ethnic and racial backgrounds can benefit the multicultural Canadian classroom by "enhancing cultural compatibility, demystifying the hidden curriculum, developing positive attitudes towards persons from a variety of backgrounds, expressing lived experiences, connecting with the students, and connecting with the communities." 37

\section{Methodology}

I approached this study with an understanding that many epistemologies are possible in the research process. I chose transnational feminist epistemology $y^{38}$ to guide my research decisions. I acknowledge the problematic nature of constructing a feminist way of doing objective research, but I am hesitant to "completely throw the idea to the wind leaving room for only absolute relativism." 39 For me, objectivity and subjectivity are not conflicting paradigms; "feminist objectivity means quite simply situated knowledges." $40 \mathrm{I}$ consider these situated and embodied knowledges as being space within knowledge creation that allows for difference, complexity, contradiction, and social change. Furthermore, I assume that knowledge production is a political and socially constructed process; it is neither universal nor separated from its process of production. This approach to knowledge and objectivity is critical for my data analysis and decisions about representation; it does not only allow for multiplicity of knowledge, but considers the role of gender, race, class, and other social constructions in the production of knowledge.

I am also cognizant of the power and authority issues embedded in my relationship with those whom I research. I understand the importance of reflexive practice and the need to question and articulate my personal and research standpoints throughout the research process. I am aware that in my research with Yugoslavian refugee women teachers, I am both an insider and an outsider to the experience. As a refugee woman teacher from the former Yugoslavia, I share some major status characteristics such as race, gender, and refugee status with participants in my study. As a cultural insider, I was able to gain easy access to the Yugoslavian refugee women teachers' population in Ontario and Quebec and to develop a rapport with these women in 
a short period of time. Sharing some characteristics with the participants, however, does not necessarily enable me to fully understand their lived experiences. ${ }^{41}$

\section{Data Collection and Analysis}

I conducted two individual, in-depth and open-ended conversations with each of the women. Each individual conversation was two to three hours long, digitally recorded, and transcribed verbatim. I also conducted two focus group conversations, one in Ontario and one in Quebec. The focus group conversation conducted in Quebec involved seven participants and lasted for four hours while the Ontario focus group conversation involved three participants and lasted for two hours. I kept notes and used a ten-minute debriefing session at the end of each focus group interview to verify the most frequent themes emerging from the conversation. I transcribed the focus groups' digital recordings using purposeful transcription (i.e., I transcribed only those lines relevant to the main stories verified during the debriefing sessions). I kept field notes and a reflexive journal to document the research process. I was also interviewed by one of my Ph.D. colleagues before I started interviewing other women to construct my personal narrative, one which will not be influenced by other women's stories. I used these conversations to explore personal and cultural assumptions and biases inherent in my interview protocol and my personal understandings of exile, settlement, and professional identity.

As I was aware that face-to-face interviews make anonymity and even confidentiality difficult to achieve, I invited participants to choose pseudonyms. Three women chose names of their family members (e.g., sisters, aunts, or nephews). One woman, however, selected the pseudonym Nina Bloom, the name of the main fictional character in Patterson and Ledwidge's novel Now You See Her. ${ }^{42}$

During transcription and data analysis, I allowed for multiple voices and subjectivities and employed poetic transcription, ${ }^{43}$ the storying stories method, ${ }^{44}$ and concentric storying 45 as alternative modes of data analysis and re-presentation. I created transcript poems using the participants' words. I first identified main stories in the transcript and condensed those stories into poems by keeping in key words and phrases while taking out prepositions, adjectives, and adverbs. I kept enough of the participants' words together to represent their "way of saying things." ${ }^{6}$ Finally, I reread each poem several times to trim the poem down to its core, trimming down for rhythm, rhyme, and memorable stories. My goal was to achieve metaphorical generalizability and "inspire an empathic, emotional reaction, so the consumer of research can develop a deep, personal understanding of the 'subject' of the data." ${ }^{27}$
In addition to transcript poems, I used the storying stories method $^{48}$ to move from digital recordings and transcripts to meaningful stories. I searched for plots while listening to recordings and typing up transcripts. I watched for what was said, how it was said, and what remained unsaid but signalled between the lines. I looked at interview transcripts through multiple lenses: active listening, narrative processes, language, context, and significant moments. ${ }^{49} \mathrm{I}$ created story subtitles and the main title for each conversation, including the first interview, the second interview, and the focus group interview. After identifying a number of subtitles and one main title for each interview, I developed an interpretative story for each interview.

I sent each transcript and synopsis including transcript poems, interpretative story subtitles, interpretative story titles, metaphors, and storying-the-researcher notes to participants for member check. After receiving the participants' approval for each transcript and for my interpretations of their words, I created an interpretative story for each of the interviews. While I was frequently revisiting the transcripts to write up interpretative stories, I noticed that each participant would mention a particular story over and over again throughout our conversations, a dominant story that embodied the core values and beliefs of the participant and offered an opportunity for creating a new story by answering the following questions: Are there similarities? Does the same theme underline the stories? Is the character passive or active? Is the conflict similar each time? Has the participant resolved the conflict in the same way? Is the mood consistent? What kind of mood is it? ${ }^{50}$ Finally, I compiled interpretative stories and dominant stories together with transcript poems and metaphors to compose a personal experience narrative of refugeehood, teaching, and teacher identity for each participant. Each personal experience narrative was sent to participants for member check and after their approval was included in this text.

To honour transnational and translingual identities of refugee female teachers from Yugoslavia, I created bilingual data sources. My conversations with refugee women teachers from Ontario were held in English. Conversations with refugee female teachers from Quebec, on the other hand, were held in the Serbo-Croatian language due to my language limitations in French. The Serbo-Croatian language was our point of connection and allowed the refugee female teachers from Quebec to be heard in English-speaking environments. All the transcript poems and quotations included in this paper from the interviews conducted in Ontario are presented in English. Poems and quotations created from the interviews conducted in Quebec and in the Serbo-Croatian language are, on the other hand, offered as bilingual text. 


\section{Starting a Collective Narrative of Refugeehood, Teaching, and Teacher Identity in Canada}

In this section of the paper, I first present Jagoda, Nada Zlata, and Nina Bloom through the summaries of their personal experience narratives including a short biography, interpretative story titles, dominant story title, personal experience narrative title, and one of their transcript poems echoing their narrative. Next, I chart the overlapping characteristics of their stories viewed through systemic and selfimposed barriers to settlement in Canada. Finally, I highlight the unique characteristics of each woman's narrative.

\section{Jagoda's Personal Experience Narrative}

Jagoda is a French and Latin language teacher from Yugoslavia. She first escaped from Bosnia and Herzegovina $(\mathrm{BiH})$, then a province of Yugoslavia, to Serbia. Jagoda and her family joined a big wave of refugees immigrating to Serbia from other Yugoslav provinces between 1991 and 1996. Due to this big wave of refugees, Serbia was experiencing a great economic crisis. Jagoda started working as a Latin language teacher in a rural area. For the next three years, she was not able to obtain Serbian citizenship. She lost her job and was forced to seek a better life outside of Serbia. She was forty years of age when she arrived in Quebec with her husband and two children. Jagoda planned to continue her education and re-establish her teaching career in Quebec, but encountered a number of personal, social, and systemic obstacles in her settlement. These obstacles convinced Jagoda to give up her teaching career. She volunteered, however, at an elementary school as a lunch supervisor and was invited by the school principal to work full-time in this capacity. Jagoda accepted the offer and continues to work as a lunch supervisor to date.

Storying Jagoda's stories...

Story Title 1:

Da sam bila mlađa [kad sam došla u Kanadu], ne bih se nikada odrekla škole.

[If I were a younger woman, I would not give up my education.]

Story Title 2:

Ne žalim što sam došla u Kanadu, ali Kanada nije moj dom.

[I don't regret coming to Canada, but Canada is not my home.]

Story Title 3:

Kanada je moja maćeha.

[Canada is my stepmother.]

Dominant Story:

Ljuta sam na Srbiju.

[I am angry with Serbia.]

Personal Experience Narrative:
Odrekla sam se škole i izgubila svoj dom

[I gave up my teacher identity and lost my home.]

\begin{tabular}{|c|c|}
\hline Odrekla sam se škole & I gave up school \\
\hline $\begin{array}{l}\text { Ulagati u sebe nema } \\
\text { smisla, }\end{array}$ & $\begin{array}{l}\text { Investing in me didn't make } \\
\text { any sense; }\end{array}$ \\
\hline jer moja djeca rastu & my children were growing up, \\
\hline i u njih ulagati treba. & it was time to invest in them. \\
\hline $\begin{array}{l}\text { Odrekla sam se škole i } \\
\text { ne žalim, }\end{array}$ & I gave up school, \\
\hline ne, ne žalim, & I have no regrets, \\
\hline $\begin{array}{l}\text { jer da sam okupirana } \\
\text { sobom bila }\end{array}$ & $\begin{array}{l}\text { I wasn't the centre of the } \\
\text { universe, }\end{array}$ \\
\hline $\begin{array}{l}\text { tko zna kakva bi se } \\
\text { nevolja zbila. }\end{array}$ & $\begin{array}{l}\text { my children's future was at } \\
\text { stake. }\end{array}$ \\
\hline
\end{tabular}

Nada's Personal Experience Narrative

Nada is a Serbo-Croatian language teacher who immigrated to Quebec from Bosnia and Herzegovina, Yugoslavia, in 1995 with her husband and two daughters. She taught the Serbo-Croatian language and literature for eleven years prior to her immigration to Quebec. Immediately after her arrival, Nada started volunteering at a second-hand store. She did not speak any French at the time. Nada tried to obtain employment as a Serbo-Croatian language teacher for Canadian solders going to Bosnia and Herzegovina after the war, but she was not accepted due to her ethnic origin. Nada's professional title is Serbo-Croatian language teacher, rather than Bosnian language teacher. For this reason, she was labelled as unqualified for this job. Despite her expertise, Nada was not able to convince her potential employers from the Canadian government that she was born in Bosnia and that she speaks the Bosnian language "koji je do juce bio srpsko-hrvatski" [which used to be Serbo-Croatian until yesterday] (i.e., before the civil war in the country).

Nada gave up her teaching career due to her limited French-language skills, her subject area (i.e., Serbo-Croatian language and literature) that was rarely needed in Quebec, and her personal characteristics, including her devotion to her family and the fact that she is not overly ambitious. She is požrtvovana majka (an overprotective mother, a mother who is willing to sacrifice her happiness for her children) and she always puts first "svu svoju porodicu a tek onda svoju profesiju" (her family and then, and only then her profession) (Conversation 1, April 2010). Nada works as a manager at the same second-hand store where she started volunteering in 1995 and manages forty people with care and grace. Nada's supervisor once noted that she looks like a teacher who keeps her classroom efficient and well organized. 
Da rata nije bilo...

Živjeli bi normalno u Jugoslaviji, imala bih 25 godina radnog staža, razmišljala o skoroj penziji,

fakultetski obrazovani, imali bi svoj stan i kuću, život mirniji.

Ovde se puno radi

i to mi malo smeta u mojim pedesetim.

Imam dvije djevojke koje će sad na fakultet, neotplaćenu kuću,

moju majku koja je daleko a pomoć joj treba.

Previse je toga na plećima mojim;

da radim,

da pomognem dok djeca ne porastu,

dok ne postanu ljudi.

Moram, moram izdržati.

Storying Nada's stories...

Story Title 1:

Mi ovdje u principu ne radimo ono što volimo nego ono što nas je zadesilo.

[We do what we are given to do, not what we desire to do.] Story Title 2:

Mi smo poklon Kanadi, Snježana.

[We are a gift to Canada, Snježana.]

Story Title 3:

Ostala sam ista: vrijedna, praktična i otvorena.

[I am still the same woman: diligent, practical and honest.]

Dominant Story:

Zadovoljna sam. Nisam ambiciozna.

[I am ok. I am not ambitious.]

Personal Experience Narrative:

"Mi smo poklon Kanadi, Snježana, ali su nam šanse male."

[We are a gift to Kanada, Snježana, but our chances to teach are slim to none.]
If the war never happened...

We would live a normal life in Yugoslavia, I would have 25 years of teaching,

I would think about retirement,

as university educated people,

we would have our apartment and house,

a life of peace.

Here, we work too much,

I am getting worn out, already in my 50s.

I have two daughters at university,

I have a mortgage,

and my mother so helpless and so far away.

My shoulders are sore;

I must work,

I must help my children,

help them grow up.

I must, I must endure.

\section{Zlata's Personal Experience Narrative}

Zlata is a Serbo-Croatian language and literature teacher who immigrated to Ontario from the war-torn Yugoslavia in 1994. Zlata and her husband came to Ontario through an immigration program for ethnically mixed-marriage couples from the former Yugoslavia at that time. As an ethnically mixed couple, Zlata and her husband did not feel safe in any of the former Yugoslav provinces. This situation provided them with the opportunity to immigrate to Canada and receive one year of financial support from the government. Zlata was in her late thirties when they landed in Ontario.

Zlata graduated from the University of Philosophy and Philology and taught Serbo-Croatian for fourteen years at the high school and university level in a large city in $\mathrm{BiH}$. She loved her profession, her students, and her colleagues. For her, teaching was a mission. Zlata found her first years in Canada difficult; she was a language teacher and spoke six languages (Serbo-Croatian, Macedonian, Slovenian, French, Spanish, and Italian), but did not speak any English at the time. Once in Canada, Zlata studied English fourteen hours a day. Her "home" was language and teaching, and she could not afford to remain homeless in Canada. Zlata works part-time as a project manager and sessional instructor at a language institute. She is, however, disappointed with the role and the place of education in Canadian society. For Zlata, the attitude towards education in Ontario is akin to the attitude of going to the shopping mall. As a university instructor, she feels lonely and disposable.

Storying Zlata's stories...

Story Title 1: 
ARE WE HERE ONLY TO ENTERTAIN!? I want to participate actively in this society.

Story Title 2:

I feel drained out and feared of being on the street, but every human being has to go through ups and downs. There is time to cry and there is time to laugh.

Story Title 3:

I feel disposable.

Dominant Story:

I'm proud of being born in Yugoslavia.

Personal Experience Narrative:

I want to participate actively in this society, but I feel disposable. ARE WE HERE ONLY TO ENTERTAIN!?

\section{I want to paint on the walls of the cave}

\author{
As humans we first thought about survival, \\ at the same time, people thought about art, \\ they described their life every day, \\ and that is missing today, you know, \\ those paintings on the walls of the cave. \\ That is what I don't feel I have, you know? \\ This is just biological existence, \\ I exist, \\ and I'm lucky that I have the theatre, \\ and literature, \\ and people who inspire me, \\ who teach me something new every day. \\ I am lucky to have the energy \\ to write a line, \\ to write a poem. \\ At work \\ only teaching inspires me. \\ After classes, I' m exhausted \\ but happy. \\ It's only that positive energy, \\ that energy what keeps me alive, \\ I am so lucky to teach! \\ My office work \\ is another story, \\ it doesn't give me that motivation, \\ that urge to paint \\ on the walls of the cave.
}

\section{Nina Bloom's Personal Experience Narrative}

Nina Bloom came to Ontario in 1995 with her husband and two sons, who were seven and nineteenyears of age at that time. She was forty-three years old and eager to teach in Ontario. Nina Bloom already had twelve years of teaching experience. Prior to her arrival to the province, she taught the Serbo-Croatian language and literature and English as second language at an elementary school in Croatia, Yugoslavia. One year after her arrival to Ontario, she obtained her TESL, TEFL, and TOEFL certificates. While studying English at an Ontario college, Nina Bloom was told by one of her instructors that she shouldn't be studying English; she should be teaching it. Soon after this event, Nina Bloom started a part-time teaching job at the college. She continued working in this capacity for eight years until the college management changed. The new management let Nina go.

Nina Bloom studied hospitality together with her older son at the same college from 1997 to 1999. Nina also worked full-time as an administrator at a hotel. She also studied adult education courses together with her younger son at a local university from 2007 to 2009. She is only five credits from her degree, but financially she cannot sustain her studies at this point of time. Nina Bloom regrets not finishing her adult education courses at a Canadian university and not teaching in Ontario. She feels fully competent, capable, and entitled to teach, but she finds the teacher recertification process in this province to be exhausting and discriminatory. She has retreated completely from this unjust process and this society.

Storying Nina Bloom's stories...

Story Title 1:

They [The Ontario College of Teachers] made it hard.

Story Title 2:

I didn't make right decisions and this is haunting me.

Story Title 3:

Žao mi je, ali ne mogu doći na grupni intervju; jedna moja prijateljica me zamolila za uslugu i ne mogu je odbiti.

[I am sorry, but I will not make to the focus group interview today; an old friend of mine asked me for a favour and I can't say no to her.]

Dominant story:

I have retreated completely.

Personal Experience Narrative:

They [the Ontario College of Teachers] made it hard and I have retreated completely.

I was better educated than my judges were

My teaching credentials weren't recognized

and this deeply affected me,

only one credit they recognized

out of 13 .

"It's not compatible," they said,

"Canadian experience you don't have."

You must have heard that line

over and over again. 


\author{
And what is, please, "Canadian experience?" \\ Is it more, \\ more valuable than Croatian, \\ Serbian, \\ Yugoslav, \\ Bulgarian? \\ Twelve years thrown away. \\ I was hurt, \\ resentful, \\ I knew, \\ I was better educated than my judges were.
}

\section{Teaching in Canada: Challenges and Opportunities}

Jagoda, Nada, Zlata, and Nina Bloom have made attempts to re-establish their teaching careers in Canada, but no woman has returned to her pre-exile professional position. In other words, no woman in this study secured permanent, full-time employment in her subject area and her school division within the Canadian context.

Jagoda encountered three self-imposed barriers to establishing her teaching career in Canada. First, Jagoda came to Quebec for her children so protecting them was her first priority. Second, she planned to continue her education and reestablish her teaching career, but she was told by one of the local school principals that her chance of getting a teaching position in Quebec, even with a teaching certificate, would be only 50-50. For Jagoda, this probability of obtaining a teaching position in the province was not good enough; she did not want to sacrifice her family time and her children's future for embarking upon such a risky adventure. Third, she trusted that coming to Quebec at the age of forty was another barrier to her professional career; she felt too old to continue her education and obliged to support her children's education rather than her own.

Jagoda also encountered financial difficulties and made some personal choices. Jagoda's husband did not speak any French when they arrived in Quebec and was not able to obtain any employment. Jagoda became the family provider, took care of her family, and paid all the bills. She could not devote any time to studying in her already busy schedule. Finally, Jagoda experienced two systemic barriers to teaching in Canada: deskilling by the education authorities in the province and discrimination by a parent who did not trust Jagoda's teaching credentials from Yugoslavia and, as a result, transferred his child to another school. With all these obstacles in front of her, Jagoda gave up teaching. She was willing to work harder than anybody else in her school, but she grew to understand that her work and her expertise would be dismissed anyway.
Nada also reported encountering two systemic barriers to her integration in Canada: lack of French language proficiency and non-recognition of her teaching credentials and experiences. She, however, argued that it was her personal choice to give up teaching in order to work, take care of her children, protect her family, and lead a humble but decent life. For Nada, family always comes first. She is more than satisfied with her managerial position at a second-hand store. Nada warns, however, that refugee women teachers are not allowed to choose their careers in Canada; they do what they are given to do. She concludes that refugee female teachers from Yugoslavia are a gift to Canada, but their chances to teach in this country are slim to none.

Zlata-who continued her education in Canada and obtained a part-time teaching position at an Ontario university-reported non-recognition of her teaching credentials and experiences as well as discrimination against refugee women in Canadian society as systematic barriers to her settlement in Canada. She is aware of individual circumstances that shape each refugee woman's life such as marital status, motherhood, age, membership in a refugee diaspora, and personal connections to people and the landscape. She argues, however, that the role of the Ministry of Immigration and Settlement, the role of the government agencies serving refugees, and the role of education authorities in Ontario are critical for the refugee women teachers' settlement in the province. Although Zlata has obtained two part-time jobs in Ontario, she feels excluded from Canadian society, a society based on the politics of difference, colonial hierarchy, and systemic marginalization of refugee and immigrant women.

Nina Bloom lives somewhere in between her Yugoslavian and her Canadian life. At first, I wondered why she chose the pseudonym Nina Bloom. To grasp the meaning of Nina Bloom's pseudonym, as well as similarities and differences between these two women, I read Patterson and Ledwidge's novel before I analyzed Nina Bloom's transcripts. In the novel, the fictional character Nina Bloom is a successful lawyer and a loving mother. ${ }^{51}$ She would do anything to protect her life built in New York-including lying to her daughter about her past. I wonder if Nina Bloom, the participant in this study, would do anything to protect the lives of her husband and her sons-including lying to everyone, even herself, about her perfect Canadian life. But when a researcher comes along asking about her teacher identity, Nina Blooms admits that her life is not perfect; she misses teaching.

Similarly to Nina Bloom, the fictional character whose secret life began eighteen years ago in New York, the participant in this study began her refugee journey fifteen years ago in Croatia, Yugoslavia. She had looks "to die for," a 
handsome caring husband, two lovely sons, and a teaching job she adored. Nina Bloom's world is, however, shattered once Yugoslavia was torn apart by civil war. She escaped war-torn Croatia and changed her identity once and for all. In Ontario, Nina Bloom experienced discrimination based on her place of origin and has completely retreated from Canadian society. She left the professional/public sphere behind and took refuge within a safe domestic sphere, sheltered by her family and her books: "I retreated completely" (Conversation 1, May, 2010). By choosing the pseudonym Nina Bloom, the participant brought up a number of gender issues including female body image (e.g., the looks to die for), vulnerability, and domestic sphere identity (e.g., being predominantly a wife and a mother).

Narratives told by Jagoda, Nada, and Nina Bloom reveal a number of self-imposed barriers (i.e., these women's personal perceptions of their capacity to learn and teach in Canada) to their settlement such as perceptions of lacking language competencies and perceptions of being "too old" to continue their education in Canada. They also discussed their choice of prioritizing motherhood and familyhood over their teacher careers. Zlata's narrative, however, proved that a lack of proficiency in the official language is not necessarily a key barrier to refugee women's settlement as is often suggested in the Western literature. ${ }^{52}$ Zlata learned English upon her arrival in Canada. She states, however, that one of the main barriers to refugee women's settlement in this country is a lack of cross-cultural knowledge among government officials serving refugees, which is often and unjustly attributed to refugee women teachers. ${ }^{53}$

In addition to self-imposed barriers to teaching, the women also identified a lack of information about the teacher recertification process, a lack of coordination between immigration and settlement services, and systemic ignorance towards international teaching credentials and experiences, as well as discrimination, as systemic barriers to their integration in the Canadian education system. For example, non-recognition of teaching credentials and experiences was characteristic of each woman's story. All the women also reported discrimination on the basis of origin and/or ethnicity.

A number of similarities emerged from women's narratives. For example, Jagoda and Nada both felt too old to continue their education in Quebec while Zlata and Nina Bloom highlighted incidents of discrimination and emotions of not belonging to Canadian society. Participants also reported some unique aspects of refugeehood. For example, Jagoda gave up her teaching career to invest her time, energy, and money in her children's education rather than her own, while Nada argued that she was not only too old to learn the language and pursue teacher recertification in Quebec but also practical and "not overly ambitious" (Individual Conversation, April 25, 2010). Another example of uniqueness can be illustrated by comparing and contrasting Jagoda's and Nina Bloom's narratives: Jagoda felt too old to continue her education in her early forties, while Nina Bloom completed college in her early fifties, started an undergraduate degree in her late fifties, and concluded: "What is life without learning" (Conversation 1, May, 2010)!?

Participants' narratives challenge Canadian stereotypes of refugee women teachers by exposing the ways in which race, class, gender, age, ethnicity, and professional status, in addition to refugeehood, shape the oppression and the privilege of refugee women in this country. Similarly to Khayatt, Narayan, and Mohanty, who critique stereotyping of racialized, immigrant, and Third World women, ${ }^{54}$ participants' stories reveal that refugee women are not uniform and inferior citizens but rather polyglots, university-educated professionals, lifelong learners, and caring mothers, as well as capable and passionate teachers whose learning and teaching "can expand the potential of human life and democratic possibilities" 55 in Canada.

\section{Coda}

Inclusion of Yugoslavian refugee women teachers' voices in narrating settlement experiences in Ontario and Quebec illuminates the ways in which settlement processes, policies, and practices shape refugee women teachers' lives in these two provinces. It is important to note that the abovementioned immigration, settlement, and education practices have not delivered their objectives of excellence, equity, and full professional integration for refugee women teachers from Yugoslavia. Canadian society fails to recognize these women as key players in the Canadian classroom and as capable and contributing citizens. Such an exclusion of refugee women teachers from Canadian schools and society might result not only in a lack of representation and diversity in the Canadian classroom, but also in a lack of equity and social justice in Canada.

Bringing to light the Ontario and Quebec settlement contexts and the dynamics of each Yugoslavian woman's story might help educators, government officials, and educational authorities in Canada understand the multi-layered social, cultural, and political space within which these women's stories and experiences are contextualized. Immigration and settlement services as well as teacher education authorities in Canada have failed Jagoda, Nada, Zlata, and Nina Bloom. However, these women prevail despite of systemic ignorance and discrimination and continue to share their wisdom with other refugee women teachers:

Izbeglim nastvnicama To refugee women teachers 


\begin{tabular}{|c|c|}
\hline $\begin{array}{l}\text { Ostanite u struci, } \\
\text { radite ono što volite, } \\
\text { učite jezik i struku paralelno, }\end{array}$ & $\begin{array}{l}\text { Stay in your profession, } \\
\text { do what you love to do, } \\
\text { learn the language and } \\
\text { profession, }\end{array}$ \\
\hline jezika se ne boj'te. & it's up to you. \\
\hline $\begin{array}{l}\text { Vase znanje i iskustvo su } \\
\text { veliki, }\end{array}$ & Don't fear any language, \\
\hline $\begin{array}{l}\text { ne gubite vreme, } \\
\text { nikada nije kasno } \\
\text { za kanadske fakultete. }\end{array}$ & $\begin{array}{l}\text { your knowledge will do, } \\
\text { your heart will grow, } \\
\text { it's up to you. }\end{array}$ \\
\hline & $\begin{array}{l}\text { Don't waste your time, } \\
\text { don't wait for the state, } \\
\text { continue your education, } \\
\text { it's never too late. }\end{array}$ \\
\hline
\end{tabular}

(Focus Group Conversation, June 13, 2010)

\section{Notes}

1. Douglas Watt, Tim Krywulak, and Kurtis Kitagawa, "Renewing Immigration: Towards a Convergance and Consolidation of Canada's Immigration Policies and Systems," Conference Board of Canada, accessed September 3, 2011, http://www.conferenceboard.ca/Libraries/NETWORK_ PUBLIC/lri2008_research_renewingimmigration.sflb.

2. UNHCR, "Convention Relating to the Status of Refugees" (Geneva: UNHCR, 1951).

3. Didi Khayatt, "The Boundaries of Identity and the Intersection of Race, Class and Gender," Canadian Woman Studies 14, no. 2 (1994): 6.

4. Uma Narayan, Dislocating Cultures: Identities, Traditions, and Third-World Feminism (New York: Routledge, 1997), 4.

5. Ibid., 4-5.

6. Chandra Talpade Mohanty, "Feminist Encounters: Locating the Politics of Difference," in Destabilizing Theory: Contemporary Feminist Debates, ed. M. Barrett and A. Phillips (Stanford, CA: Stanford University Press 1992), 87.

7. Chandra Talpade Mohanty, Feminism without Borders: Decolonizing Theory, Practicing Solidarity (Durham, NC: Duke University Press, 2003), 7.

8. Chandra Talpade Mohanty, "US Empire and the Project of Women's Studies: Stories of Citizenship, Complicity and Dissent," Gender, Place and Culture: A Journal of Feminist Geography 13, no. 1 (2006): 17.

9. Vesna Nikolić-Ristanović, Women, Violence and War: Wartime Victimizations of Refugees in the Balkans, (Budapest: Central European University Press, 2000), 152.

10. Susan Walsh, Susie Brigham, and Yina Wang, "Internationally Educated Female Teachers in the Neoliberal Context: Their Labour Market and Teacher Certification Experiences in Canada," Teaching and Teacher Education 27 (2011): 657.
11. JoAnn Phillion, "Obstacles to Accessing the Teaching Profession for Immigrant Women," Multicultural Education 1, no. 1 (2003): 41; Hanna Ragnarsdóttir, "Internationally Educated Teachers and Student Teachers in Iceland: Two Qualitative Studies," Canadian Journal of Educational Administration and Policy 100 (2010): 1.

12. Dragana Medic, "Foreign Trained Teachers: The Emergence of the Right to Practise Their Profession in Ontario" (master's thesis, Brock University, St. Catharines, ON, 2007).

13. Angela Rhone, "Caribbean-Immigrant Educators: More Than an Ocean of Difference," Childhood Education 84, no. 1 (2007): 44.

14. Susan George, "A Short History of Neoliberalism: Twenty Years of Elite Economics and Emerging Opportunities for Structural Change" (paper presented at the conference on economic sovereignty in a globalizing world, Bangkok, Thailand), accessed January 10, 2009, http://www .globalexchange.org/campaigns/econ 101/neoliberalism .html.

15. Wendy Brown, "American Nightmare: Neoliberalism, Neoconservatism, and Dedemocratization," Political Theory 34, no. 6 (2006): 695.

16. Guida Man, "Gender, Work and Migration: Deskilling Chinese Immigrant Women in Canada," Women's Studies International Forum 27, no. 2 (2004): 135; Shahrzad Mojab, "De-skilling immigrant women," Canadian Woman Studies 19, no. 3 (1999): 123.

17. Nikolić-Ristanović, Women, Violence and War: 152.

18. Audrey Macklin, "Women as Migrant: Members in National and Global Communities," Canadian Woman Studies 19, no. 2 (1999): 24.

19. Marika Morris and Jennifer Sinnott, "Immigrant and Refugee Women," Canadian Research Institute for the Advancement of Women, accessed April 7, 2012, http://www .criaw-icref.ca/ImmigrantandRefugeeWomen.

20. Ibid.

21. Ibid

22. Macklin, "Women as Migrant."

23. Morris and Sinnott, "Immigrant and Refugee Women."

24. Roxana Ng and H. Hongxia Shan, "Lifelong Learning as Ideological Practice: An Analysis from the Perspective of Immigrant Women in Canada," International Journal of Lifelong Learning 29, no. 2 (2010): 169-184.

25. George J. Sefa Dei, Sonia James-Wilson, and Jasmine Zine, Inclusive Schooling: A Teacher's Companion to Removing the Margins (Toronto: Canadian Scholars' Press, 2002); S. Nombuso Dlamini, "From the Other Side of the Desk: Notes on Teaching about Race When Racialised," Race, Ethnicity and Education 5, no. 1 (2002): 51; S. Nombuso Dlamini and Dragana Martinovic, "In Pursuit of Being Canadian: Examining the Challenges of Culturally Relevant Education in Teacher Education Programs," Race, Ethnicity and Education 10, no. 2 (2007): 155. 
26. Benedicta Egbo, Teaching for Diversity in Canadian Schools (Don Mills: Pearson Education, 2009); Denise E. Armstrong and Brenda J. McMahon, eds., Inclusion in Urban Educational Environments: Addressing Issues of Diversity, Equity, and Social Justice (Greenwich, CT: Information Age Publishing, 2006).

27. Armstrong and McMahon, eds., Inclusion in Urban Educational Environments; Dlamini and Martinovic, "In Pursuit of Being Canadian".

28. Dlamini and Martinovic, "In Pursuit of Being Canadian".

29. Dlamini, "From the Other Side of the Desk," 52.

30. Henry A. Giroux, "Resisting Difference: Cultural Studies and the Discourse of Critical Pedagogy, in Cultural Studies, ed. L. Grossberg, C. Nelson, and P. Treichler (New York: Routledge, 1992): 209.

31. Henry A. Giroux, Border Crossings: Cultural Workers and the Politics of Education (New York \& London: Routledge, 2005): 24 .

32. Ibid., 24.

33. Ibid., 26.

34. Dlamini, "From the Other Side of the Desk," 64.

35. Ibid.

36. Dei, James-Wilson, and Zine, Inclusive Schooling, 176.

37. Paul R. Carr and Thomas R. Klassen, "Different Perceptions of Race in Education: Racial Minority and White Teachers," Canadian Journal of Education 22, no. 1 (1997): 70 .

38. Interpal Grewal and Caren Kaplan, eds., Scattered Hegemonies: Postmodernity and Transnational Feminist Practices (Minneapolis: Minnesota Press, 1994); Chandra Talpade Mohanty, "Under Western Eyes: Feminist Scholarship and Colonial Discourses," Boundary 12, no. 2 (1992): 333-358; Chandra Talpade Mohanty, "Under Western Eyes Revisited: Feminist Solidarity through Anticapitalist Struggles," Signs: Journal of Women in Culture and Society 28, no. 2 (2002): 499-535.

39. Tanya Bahkru, "Negotiating and Navigating the Rough Terrain of Transnational Feminist Research," Journal of International Women's Studies 10, no. 2 (2008): 209.

40. Donna Haraway, "Situated Knowledges: The Science Question in Feminism and the Privilege of Partial Perspective," Feminist Studies 14, no. 3 (1991): 575-599.

41. Chaterine Kohler Riessman, "When Gender Is Not Enough: Women Interviewing Women," Gender and Society 1 (1987): 172-207; Josephine Beoku-Betts, "When Black Is Not Enough: Doing Field Research among Gullah Women," NWSA Journal 6 (1994): 413-433.

42. James Patterson and Michael Ledwidge, Now You See Her (New York: Little, Brown, 2011).

43. Laurel Richardson, "The Consequences of Poetic Representation," in Investigating Subjectivity: Research on Lived Experience, ed. C. Ellis and M. G. Flaherty (Newbury Park:
Sage, 1992); Laurel Richardson, "Nine Poems," Journal of Contemporary Ethnography 23, no. 1 (1994): 3-13; Corrine Glesne, "That Rare Feeling: Re-presenting Research through Poetic Transcription," Qualitative Inquiry 3 (1997): 202-221, accessed July 20, 2011, http://dx.doi .org/10.1177/107780049700300204.

44. Coralie McCormack, "From Interview Transcript to Interpretive Story: Part 1-Viewing the Transcript through Multiple Lenses," Field Methods 12, no. 4 (2000): 282-297, accessed November 11, 2009, http://dx.doi .org/10.1177/1525822X0001200402; Coralie McCormack, "From Interview Transcript to Interpretive Story: Part 2Developing an Interpretive Story," Field Methods 12, no. 4 (2000): 288-315.

45. Anne Elliott and Susan Drake, "Concentric Storying: A Vehicle for Professional Development in Teacher Education" (paper presented at the Ontario Educational Research Council, December 1999).

46. Glesne, "That Rare Feeling."

47. Rich Furman, Cynthia Lietz, and Carol L. Langer, "The Research Poem in International Social Work: Innovations in Qualitative Methodology," International Journal of Qualitative Methods 5, no. 3 (2006): 25.

48. McCormack, "From Interview Transcript to Interpretive Story: Part 1"; McCormack, "From Interview Transcript to Interpretive Story: Part 2."

49. Ibid.

50. Elliott and Drake, "Concentric Storying."

51. Patterson and Ledwidge, Now You See Her.

52. Phillion, "Obstacles to Accessing the Teaching Profession for Immigrant Women"; Ragnarsdóttir, "Internationally Educated Teachers and Student Teachers in Iceland."

53. Medic, "Foreign trained teachers"; Rhone, "CaribbeanImmigrant Educators.".

54. Khayatt, "The Boundaries of Identity"; Narayan, Dislocating Cultures; Mohanty, "Feminist Encounters."

55. Giroux, "Border Crossings."

Snežana Ratković is a science teacher from the former Yugoslavia who immigrated to Canada in 1998, after the civil war in the country. She works as research officer in the Faculty of Education at Brock University, St. Catharines, Ontario, Canada. Her research focuses on forced migration and settlement, teacher identity, teacher education, research ethics, and social justice studies. She has published in The Reading Professor, Forum Qualitative Sozialforschung / Forum: Qualitative Social Research, South African Journal of Higher Education, Power and Education, Educational Action Research Journal, Studies in Higher Education, and Brock Education. 